\title{
Review Article: Genetics and Breeding Overview for Coffee Wilt Disease Resistance
}

\author{
Admikew Getaneh Yigletu \\ Ethiopian Institute of Agricultural Research, Jimma Agricultural Research Center, P. O. Box, 192, Jimma, \\ Ethiopia
}

\begin{abstract}
The presence of intra- and inter specific variability in the coffee species provide a potential source of resistance to coffee wilt disease (CWD). Additionally, the existence of Robusta and Arabica wilt pathogenic forms enables to design effective breeding strategies to develop resistant cultivars towards each population. The inheritance of resistance to Fussarium xylarioides in Coffea canephora suggested that resistance is controlled by polygenic. Heritability is low to moderate with low genetic gains of choosing a progeny of resistant parents as source of planting materials; so that resistant clones should be propagated vegetatively. Alternatively, in Arabica CWD resistance has been suggested that presence of certain quantitative with qualitative resistance. Moreover, Arabica coffee was lacking or low heterosis for resistance, predominance of additive over non additive genetic effects and estimated of high heritability coupled with genetic advance as percent of mean (GAM) for resistance and incubation period; indicated that selection and hybridization are important to improve population and to obtain segregating generation, respectively. The resistant Arabica coffee genotypes were also significantly associated with extended incubation period, leaf area, stem diameter and minimum number of defoliated leaves than the susceptible genotypes. For further screening, promising resistant Arabica coffee genotypes were planted and also under evaluation for other major diseases, yield and quality traits at sick plot of Gera agricultural Research Sub Center, Ethiopia. Generally, CWD symptoms, source of resistance, host-pathogen interaction, resistance screening techniques, genotypes evaluation, inheritance of resistance, hybridization and resistant variety development approaches were comprehensively discussed.
\end{abstract}

Keywords: Coffee Wilt Disease, Coffea Arabica, Coffea canephora, Resistance

DOI: $10.7176 / \mathrm{JBAH} / 9-7-10$

Publication date: April $30^{\text {th }} 2019$

\section{Introduction}

Coffee wilt disease (tracheomycosis) is a fungal vascular disease caused by Fusarium xylarioides or the sexual reproductive stage, Gibberella xylarioides (Kranz and Mogk, 1973). Its symptoms progress from inward curling and wilting of leaves to die back and death of affected trees. The disease kills its host at all ages within a short period. The pathogen survives in the soil for several years after uprooting and removing infected trees, and difficult to control using fungicides (Musoli et al., 2008). However, it may be controlled by the use of antagonistic fungi such as Trichoderma species in-vitro up to 71\% (Alemu, 2012). The use of resistant variety is the most appropriate, cost effective and sustainable method for CWD management. Moreover, understanding the type of resistance and inheritance of the resistance are vital for breeding strategies and resistant variety development (Girma et al., 2009; Musoli et al., 2009). A crossing program had been achieved to know the genetics of resistance both in Robusta and Arabica coffee (Musoli et al., 2013; Admikew, 2017).

There has been enormous effort to develop resistant varieties to control CWD in Ethiopia, Uganda and Tanzania. In Uganda, Robusta coffee genotypes with variable levels of resistance have been identified and used for introgression of resistance into current susceptible commercial clones (Musoli et al., 2013). In Ethiopia, a varietal pattern of attack observed between Arabica coffee genotypes. Seedling test and conidium germination test on six host genotypes with four G. xylarioides isolates concluded that horizontal resistance nature of CWD (Pieters and Van der Graaff, 1980). According to Girma et al. (2001) and Girma (2004), there were an evidences indicating variations in resistance or tolerance levels in Arabica coffee genotypes under field conditions. Additionally, most Bale (Harena) forest Arabica coffee genotypes showed resistance reaction to CWD (Arega, 2006; Sihen et al., 2012; Kifle et al., 2015). Furthermore, the presence of Robusta and Arabica wilt pathogenic forms enables to design effective breeding strategies to develop resistant cultivars towards each population group (Girma et al., 2005). The goal of the paper is to review the genetics and breeding status of CWD resistance and the way forward to develop resistance cultivars.

\section{Coffee wilt disease}

CWD is a fungal vascular wilt disease that caused by the anamorph or teleomorph stages $F$. xylarioides or $G$. xylarioides (Steyaert, 1948; Heim and Saccas, 1950; Kranz and Mogk, 1973). The pathogen invades the coffee tree and colonizes the xylem system. The production of coffee is today severely affected by this fungal disease (Silva et al., 2006; Serani et al., 2007). The disease is responsible for a reduction in the production of coffee 
beans and is also accompanied by severe damage and death of millions of coffee bushes (Girma et al., 2001). CWD leads to about $37 \%$ reduction of coffee production (yield) at the farm level (from 1482 to $932 \mathrm{~kg}$ per sample farm); this led to a decline of income by $67 \%$ and the annual national crop losses attributed about 3360 tons. In Ethiopia, CWD incidence and severity is about $28 \%$ and $5 \%$ respectively. However, it varied from place to place in the range of 0 to $100 \%$ for incidence and 0 to $25 \%$ for severity (CABI, 2003).

CWD is present in four African countries (Democratic Republic of Congo (DRC), Uganda, Tanzania and Ethiopia) and a major production constraint (Figure 1). Across the countries surveyed, a total of 1728 out of the 5505 farms (31\%) were found to be infested with the disease; 1280 farms with Robusta coffee $(75 \%)$ and 448 farms with Arabica coffee (12\%). However, the disease is far from evenly distributed throughout the sampled countries and severity ranged from 0 in Rwanda to $45 \%$ in Uganda (Phiri and Baker, 2009).

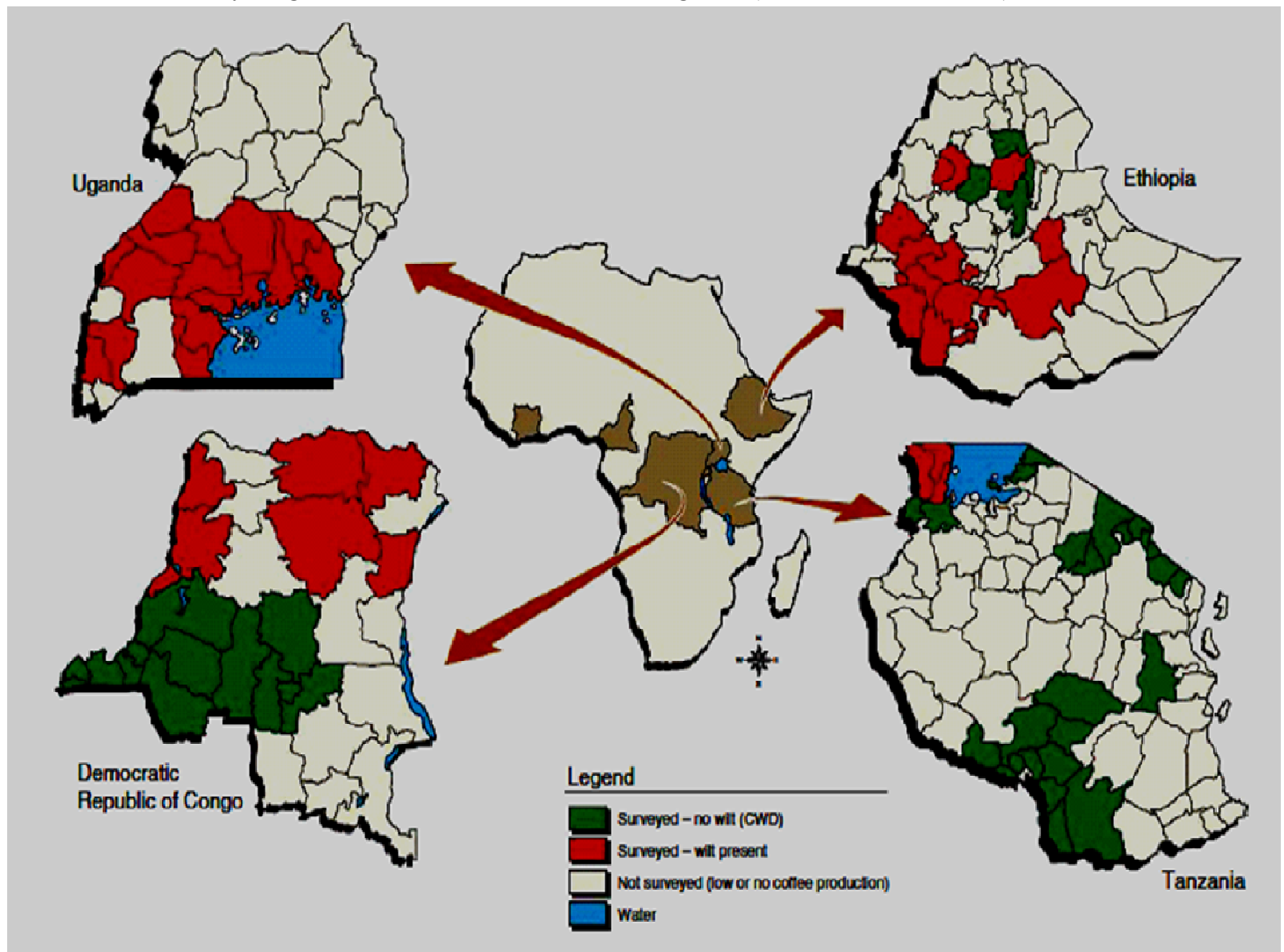

Figure 1: Coffees wilt disease distribution in Africa (Phiri and Baker, 2009).

\section{Coffee wilt disease symptoms}

The disease manifests itself after a prolonged incubation period by expression of disease symptoms (Kranz and Mogk, 1973). Generally, CWD symptoms progress from inward curling and wilting of leaves to die back and death of affected trees as shown in Figure 2. Symptoms may appear at any growth stage and the rate of development varies in each stage. Once a tree affected, death is inevitable. In mature trees, death is usually occurs between 3 and 15 months after the first symptoms appearance. Symptoms can be more pronounced on one part of the tree and a likely consequence of initial infection occurring on one of several main stems, but defoliation or wilting gradually extends to the entire plant or seedling (Figure 2a, 2c and 2d). Coffee berries that would normally be green may redden as if ripening prematurely, but often remain intact on shoots following defoliation. Characteristic bluish-black staining of the wood can be observed directly beneath the bark (Figure $2 b$ ). Furthermore, small blackish-brown perithecia (sexual stage) of the fungus may be produced in the cracks of the bark. (Rutherford et al, 2009). As a result, the disease kills its host at all ages within a short period and infested soil may remain infective for several years after uprooting and removing the infected trees (Musoli et al., 2008). 


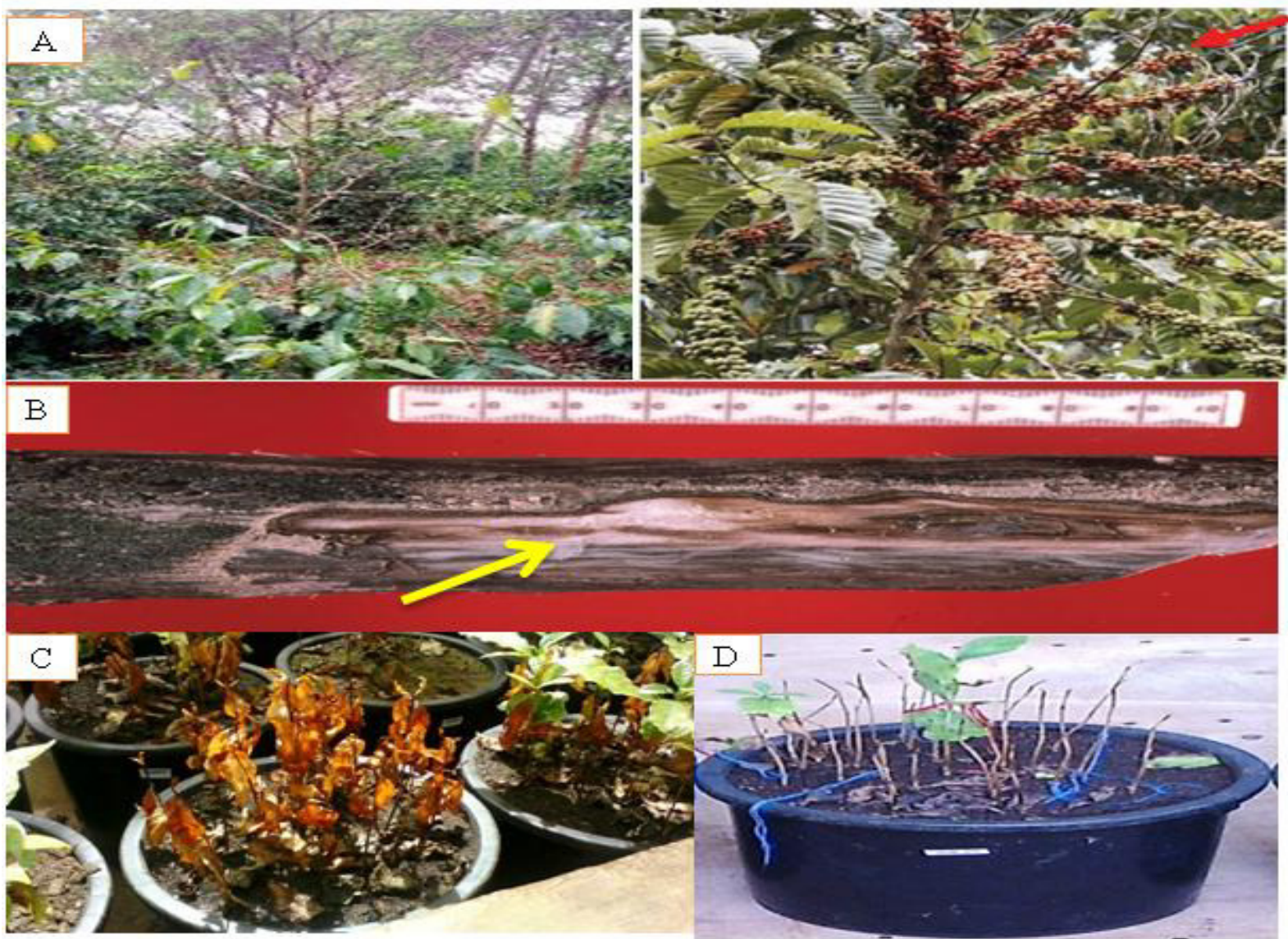

Figure 2: Coffee wilt disease symptoms A) Chlorotic, leaf curling and dieback on one side of a branch B)Brown or blue-black coloration under the bark (Phiri and Baker, 2009) C) Wilting and D) Defoliant types of symptoms (JARC, 2016).

\section{Breeding status for resistance}

Resistance to wilt disease depends in part on genetic potential for virulence within the pathogen populations, the inoculum's concentration and the genetic potential of the host (Beckman, 1987). The resistance of a plant (or tissue) changes sequentially during growth and development; thus, certain growth stages are more favorable than others for comparison of resistant and susceptible cultivars. Attempts to control CWD are fundamentally based on the breeding of resistant plants, environmental management, and synthetic fungicide application (Strange, 1993).

\section{Potential sources of resistance}

The source of genes for resistance is the same gene pool of the crop that provides genes for inherited resistant characteristic; namely, new breeding lines, older cultivars, abandoned cultivars, earlier or discarded breeders' stock, wild relatives, other native or foreign commercial varieties, and induced mutation plants (Agrios, 2005). Intra and inter specific differences of coffee species provide a potential source to exploited CWD resistance. Intra-specific variability is the best and easiest to exploit since resistant individuals are easily released as new varieties without undergoing hybridization, if it possessed high yielding, resistance to other major diseases and good qualities (Musoli et al., 2009). Particularly, C. canephora is genetically diverse due to out-breeding and wide geographical distribution (Leakey, 1970; Musoli, 2007).

Significant genetic differences were showed for CWD resistance between Kibale, Itwara and Kalangala $C$. canephora forest populations with Erecta and Nganda morphological types through artificial inoculation in a screen house at Uganda. The report showed that Kalangala and Itwara populations plus the Erecta type showed resistance reaction. Generally, breeding program in Uganda has screened about 1500 CWD resistant Robusta line; further screening and evaluation for other important traits reduced to seven lines (Musoli et al., 2009; Phiri and Baker, 2009). Furthermore, in Tanzania, 875 Robusta lines were screened and six resistant lines were selected (Kilambo et al., 2012).

A number of researchers have reported the existence of marked differences in resistance levels in Arabica coffee populations to CWD under field conditions and the genetic diversity is high enough to exploited for 
resistance (Van der Graaff and Pieters, 1978; Merdassa, 1986; Girma et al., 2001; Girma, 2004). Based on standard screening procedures varieties Catimor J-19, Catimor J-21, 7440 and Merdacheriko showed resistant to moderately resistant (Girma, 2004). Moreover, according to Chala et al. (2012), 971 (Fayate) and 974 (Odicha) varieties indicates resistant reaction. Demelash (2013) also reported that 370 and 279/71 genotypes were CWD resistant as compared to standard resistant check (Catimor J-19). Additionally, southeast Ethiopia (Harena) forest coffee collections exhibited lower seedling death rate (CWD resistance) under laboratory conditions (Arega, 2006; Sihen et al., 2012; Kifle et al., 2015).

\section{Coffee - G. xylarioides interaction}

The study of host-pathogen associations involves a three-dimensional interaction; between host, pathogen strains and environmental variables that can affect disease expression. To be able to limit the effect of these factors on host-pathogen interactions, standard artificial screening protocols that discriminate between resistant and susceptible genotypes have been developed. Different inoculation procedures, such as stem nicking, root dipping and syringe injection have been used to screen and identify CWD resistant genotypes by different countries (Pieters and Van der Graaff, 1980; Girma and Mengistu, 2000; Musoli, 2007). Thus, standardizing the inoculation protocols (methodologies), identifying proper growth stages of the host that show differential reactions, selection of aggressive strain/isolate and conditions that favor infection and wilt disease development are paramount importance in designing an effective screening and CWD resistance breeding program (Girma et al., 2009).

In general, the wilt pathogen enters into tree roots either through wounds or directly through root hairs and the epidermis of the small roots (Toole, 1941). Once a pathogen has penetrated a suitable host through wounds, it moves to the vascular tissue. The pathogen then spread throughout the plant by means of mycelia growth or conidia and primarily micro conidia; produced in infected xylem vessel elements as shown in Figure 3 (Agrios, 2005). As the disease development progresses, the fungus invades tissues adjacent to the xylem tissues such as pith, cambium, phloem, and cortex. Colonization of the vascular system induces host responses, which disrupt water conduction and the pathogen materials clog the water upward movement (Nelson, 1981).

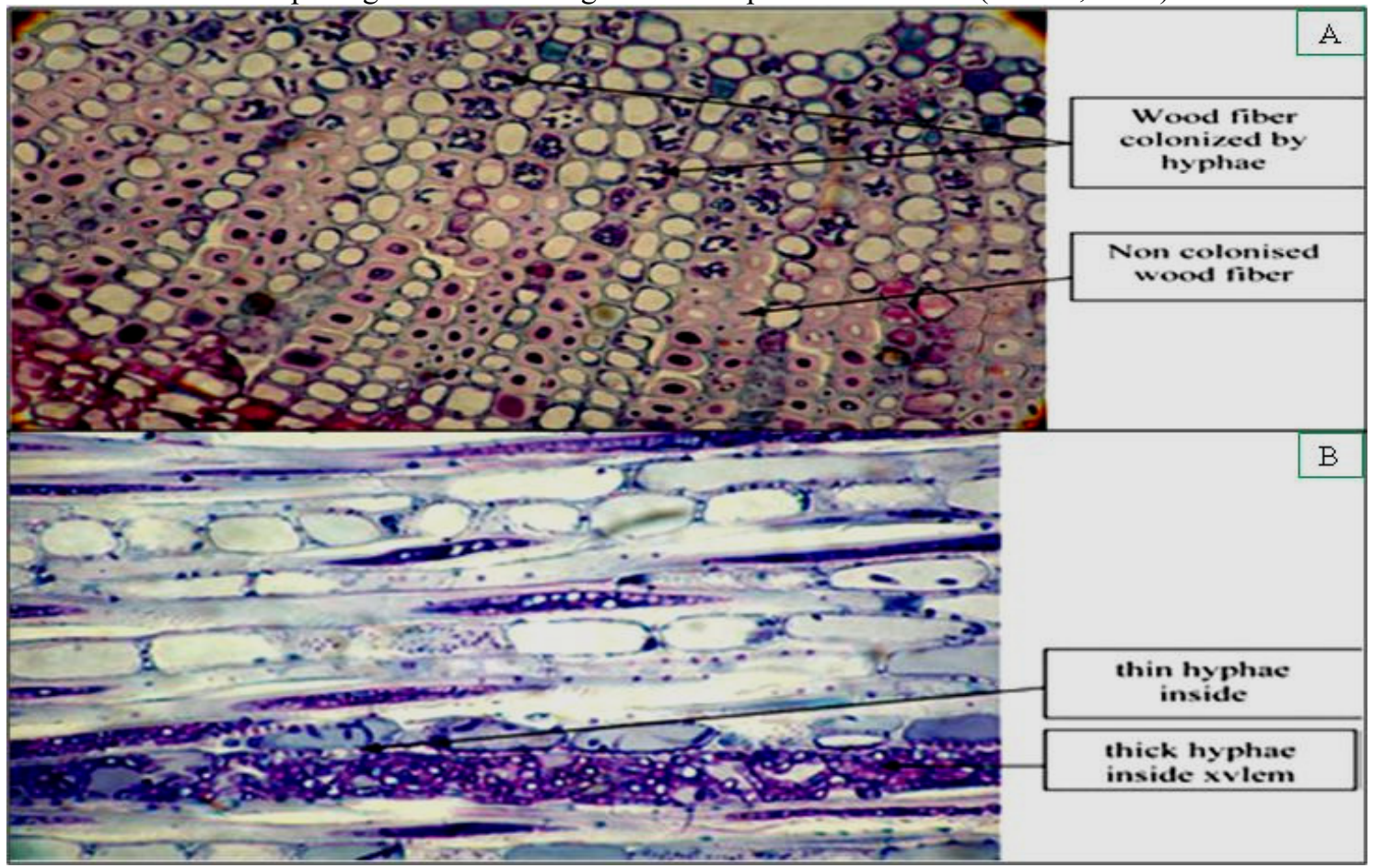

Figure 3: G. xylarioides - Coffea canephora interaction at cellular level A) Cross section of a 9 month old infected seedling B) Hyphal colonization of vascular tissues of 18 month old infected seedling (Musoli et al., 2009).

\section{Artificial inoculation and screening techniques}

Use of a quick and effective CWD resistance screening protocols is crucial to the successful and reliable identification of resistant genotypes under natural and artificial infections. There are more methodological variations when assessing genotypes for resistance in artificial conditions (Musoli et al., 2009). Different inoculation procedures have been used for artificially inoculating coffee plants when testing them for resistance (Van der Graaff and Pieters, 1978; Bieysse, 2005; Musoli, 2007). Each inoculation method has its own 
advantages and drawbacks; and the method is adopted based on relative importance for each country. Under a comprehensive experiments, stem-nicking method with 2 to $2.5 \times 106$ pathogen inoculums concentration at cotyledon stage ( 2 to 2.5 months old) using a scalpel has been adopted as the preferred standard protocol for screening Arabica coffee germplasm and studying the host-pathogen interaction in Ethiopia (Pieters and Van der Graaff, 1980; Girma and Mengistu, 2000; Girma et al., 2005). Whereas, root dipping inoculation with $1.3 \times 106$ conidia per milliliter of water) procedure is employed in screening Coffea canephora seedlings (5 to 6 months old) in Uganda, DRC and Tanzania (Musoli, 2007; Kilambo et al., 2007).

In general, inoculum concentration, isolate differences, coffee growth stage, genetic constitutions of the genotypes, pre- and post-inoculation conditions are known to influence infection and disease development. Study showed that inoculated seedlings is maintained at high humidity $(>95 \%)$ and temperature of about $23 \mathrm{oC}$ for a week as optimum conditions for infection. Disease parameters such as number of wilted seedlings (wilted seedling percentage) and incubation period should be recorded for at least 6 months in green house test (Girma and Mengistu, 2000; Girma et al., 2009). Result showed that increasing inoculums concentration leads to reducing incubation time and increasing wilt incidence. Furthermore, shorter seedlings exposure period (for 20 min) in the inoculum's is enough for infection and disease development (Musoli et al., 2009). Thus, most investigators settled that standardizing the inoculation protocols (methodologies) across different laboratories or greenhouses, identifying proper growth stages of the host, selection of aggressive strain (isolate) and conditions that favor infection and wilt disease development are paramount in designing an effective screening and resistance breeding program (Girma et al., 2009; Musoli et al., 2009).

To optimize the protocol, a comprehensive investigation was carried out in three Arabica genotypes (designated as resistant, intermediate and susceptible) from known field observations with a standard Arabica $G$. xylarioides isolate $(2 \times 106$ spore per milliliter) at four different growth stages of seedlings employing five inoculation methods; namely, stem nicking, stem injection, root cutting and dipping, root wounding and transplanting into artificially and naturally infested soil. There were highly significant differences between coffee genotypes, inoculation methods and growth stages of the seedlings among the three variables (Figure 4A and B). Cotyledon and one pair of true leaf stages showed significantly higher seedling death (Figure 4A). When different inoculation methods compared, significantly the highest percentage deaths were recorded in stem nicking followed by the root dipping and stem injection methods as shown in Figure 4b (Girma et al., 2009).

CWD resistance should be quantified for selection of genuinely resistant genotypes and comparison of results among experiments and genotypes. In Uganda, there is method to quantifying coffee plants studied in artificial inoculations; commonly assessed on a scale of 1 to 5 ; where $1=$ no disease, $2=$ curling leaves and stunted growth, 3 = leaf wilting and yellowing, $4=$ leaf necrosis, leaf wilting, and abscission and $5=$ dead plants (Musoli et al., 2009). Mature coffee plants in the field also assessed on 1 to 5 scales; $1=$ no disease, $2=1 \%-25 \%$ defoliation, $3=26 \%-50 \%$ defoliation, $4=51 \%-75 \%$ defoliation and $5=76 \%-100 \%$ defoliation and wilted. In Ethiopia, resistance among genotypes is quantified as wilted seedling percentage. There is also an attempt to quantify relative resistance among coffee genotypes using incubation period even though it has its own drawback (Pieters and Van der Graaff, 1980; Girma and Mengistu, 2000). Since, all plants that develop CWD symptoms eventually die, only plants without the symptoms after a long period of infection (6 months for plants in artificial inoculations and not less than 5 years for plants evaluated in heavily infested fields) were considered to be resistant (Musoli et al., 2009). 


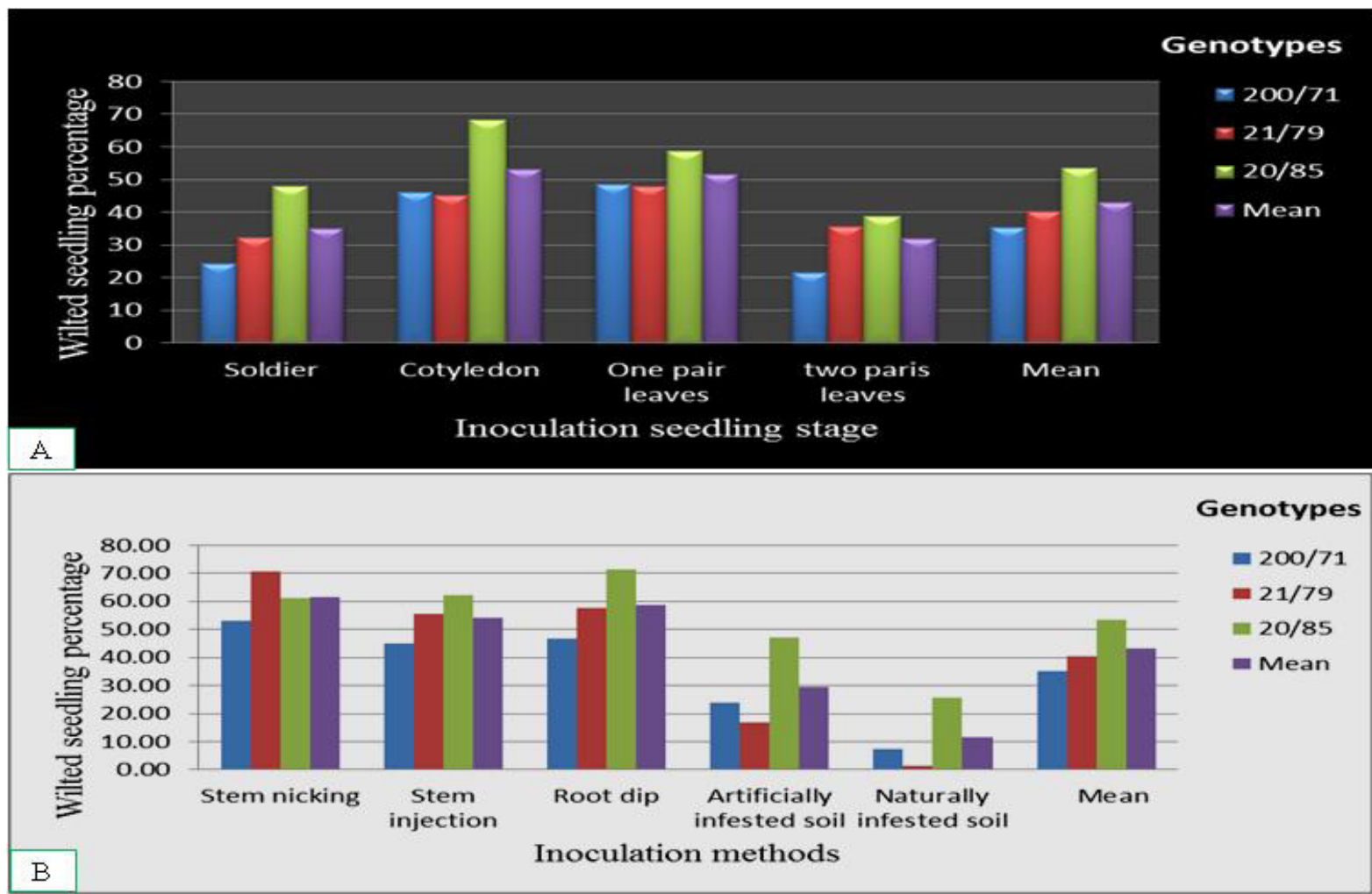

Figure 4: Wilted seedling percentage of three different Arabica coffee genotypes inoculated with standard G. xylarioides isolates at greenhouse A) different growth stages B) different inoculation methods.

\section{Evaluation of coffee genotypes for CWD resistance}

At different time of artificial inoculation and screening programs, thousands of Arabica coffee genotypes are examined at seedling stage by different investigators in Ethiopia. Reports showed that there is variable resistance levels and able to identify resistant genotypes (Van der Graaff and Pieters 1980; Girma, 2004; Girma et al., 2005; Arega, 2006; Chala et al., 2012; Sihen et al., 2012; Demelash, 2013; Demelash and Kifle, 2015; Kifle et al., 2015). In addition, Coffea arabica has marked differences for CWD resistance at field conditions (Van der Graaff and Pieters, 1978; Merdassa, 1986; Girma et al., 2001; Girma, 2004). Twelve Arabica coffee genotypes were tested from diverse agro ecological zones with different resistance reactions (resistant, moderately resistant and susceptible) based on artificial inoculation test or natural CWD infested soils in order to verify previous results and select promising resistant genotypes (Figure 5). The study confirmed that genotypes 279/71, 971, 974 and 79233 exhibited low wilted seedling percentage or promising resistant genotypes, minimum number of defoliated leaves and extended incubation period compared to other genotypes. Therefore, these genotypes are important for inclusion in future resistance breeding programs (Admikew, 2017). Currently, in Ethiopia, an organized field evaluation and screening is under way starting from 2013.

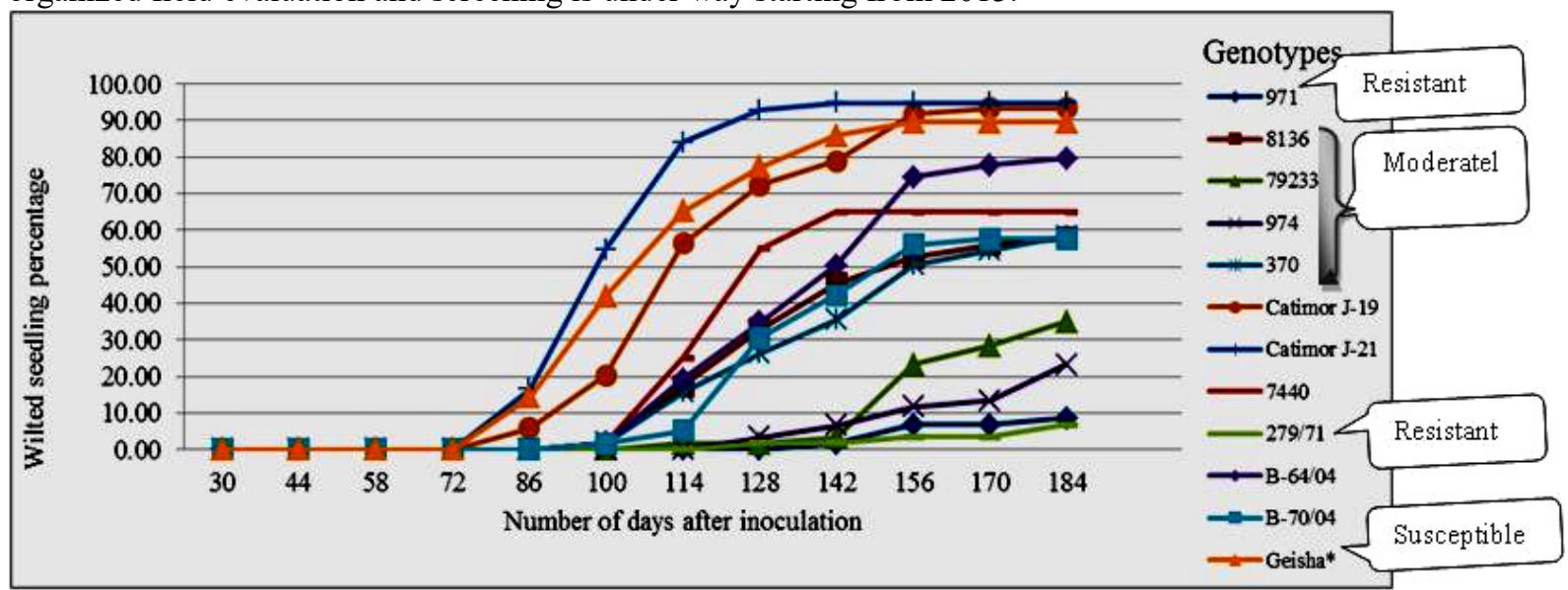

Figure 5: Arabica coffee genotypes wilted seedling percentage progress on time trend in artificial inoculation test. 
Open pollinated seedlings of diverse $C$. canephora genotypes, which included two cultivated distinct morphological types (erecta and nganda), wild populations from Kibale and Itwara forests and feral population from Kalangala were assessed and the populations showed that highly significant genotypic differences (disease progressed at different rates for different genotypes) for resistance in artificial inoculation test at Uganda. In DRC and Tanzania, different $C$. canephora genotypes also showed varying levels of resistance (Kalonji-Mbuyi et al., 2009; Kilambo et al., 2012). Resistant genotypes selected through field observations can withstand high disease pressures under different agro-ecological conditions if they tested under a range of environmental conditions. Studies carried out on mature $C$. canephora clones revealed that variable responses to infection at field in Uganda. As shown in Figure 6, clones $\mathrm{J} / 1 / 1, \mathrm{Q} / 3 / 4, \mathrm{R} / 1 / 4$ and $1 \mathrm{~s} / 3$ showed no to low wilted seedling percentage (resistant) after five years of data assessment (Musoli, et al., 2009).This showed that the clones had variable levels of resistance and the resistance is most likely governed by many genes (Musoli et al., 2013).

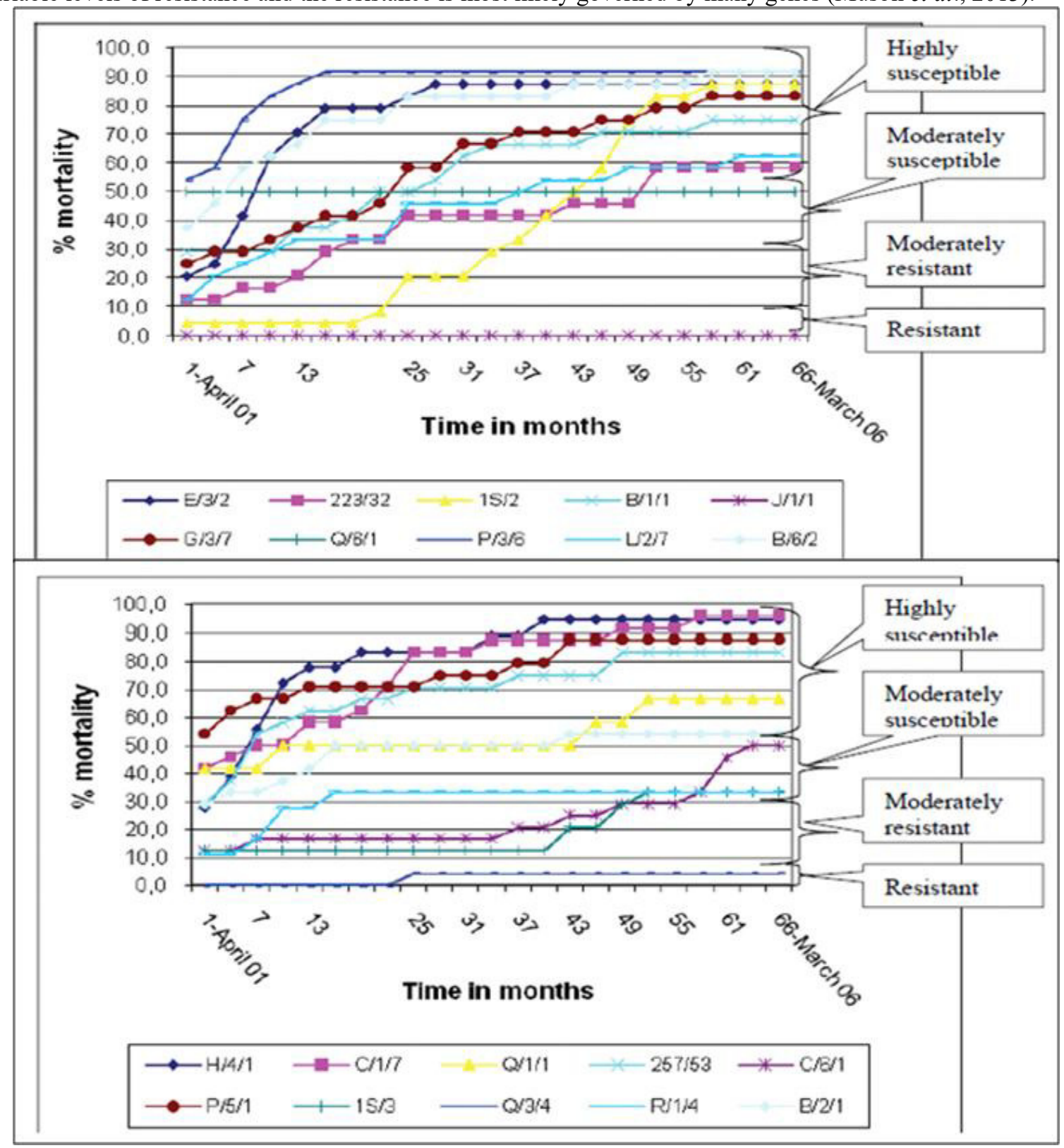

Figure 6: Progression of tree mortality of $C$. canephora clones for $C W D$ resistance at naturally infected field (Musoli et al., 2009).

Over years (tested period of genotypes by authors) summarized coffee genotypes wilted seedling percentage is shown in table 1 . The genotypes were tested for the disease at different time; and result showed that some variation in the same genotypes by different authors. This is probably due to precision of inoculation, differences in pathogen aggressiveness, green house environmental change specially temperature, period and season of inoculation. Periodical genotype variation also indicates horizontal resistance nature of the disease. Cumulative period result of Arabica coffee genotypes 279/71 followed by 971 (Feyate) and 974 (Odicha) 
showed low wilted seedling percentage or CWD resistance; while, genotypes Geisha and SN-5 showed susceptible reaction. Recent examination result showed that most tolerant or resistant genotypes were degraded its nature of resistance as compared to previous as shown in Table 1. It might be also due to the above mentioned conditions.

Table 1: Summary of previous reports on repeatedly tested Arabica coffee genotypes wilted seedling percentage.

\begin{tabular}{|c|c|c|c|c|c|c|c|c|c|c|c|c|c|}
\hline \multirow[b]{2}{*}{ Authors } & \multirow[b]{2}{*}{ Traits } & \multicolumn{12}{|c|}{ Arabica coffee genotypes } \\
\hline & & Feyate & Odicha & 370 & Merdacheriko & 7440 & $\begin{array}{l}\text { Catimor } \\
\text { J-19 }\end{array}$ & $\begin{array}{l}\text { Catimor } \\
\text { J-21 }\end{array}$ & 79233 & SN-5 & Geisha & $279 / 71$ & $200 / 71$ \\
\hline \multirow{2}{*}{ Girma, 2005} & $\mathrm{WS} \%$ & - & - & - & 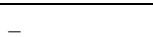 & 47.5 & 22.7 & +2 & - & - & - & - & - \\
\hline & IP & - & - & - & - & 97.5 & 76.6 & _ & _- & & _- & _ & _- \\
\hline \multirow{2}{*}{ Arega, 2006} & WS\% & - & - & - & - & 72.2 & 0 & - & - & $\overline{9} 2.4$ & _ & _ & _ \\
\hline & IP & - & - & - & - & 95.3 & + & & - & 105 & & - & \\
\hline \multirow{6}{*}{$\begin{array}{l}\text { Girma and } \\
\text { Chala, 2008 } \\
\text { Girma et al., } \\
2009 \\
\text { Chala et al., } \\
2012\end{array}$} & WS $\%$ & _ & - & _ & 25.3 & 40.4 & 12.7 & 63.3 & _ & 69.7 & 88.1 & _ & 15.2 \\
\hline & IP & - & - & - & 150 & 135 & 157.5 & 140.8 & - & 119 & 97.5 & - & 152.5 \\
\hline & WS\% & - & - & - & - & 12.0 & - & - & - & 45.0 & - & - & 53.1 \\
\hline & IP & & & & - & 112.0 & - & & - & 70.0 & _- & - & - \\
\hline & WS\% & 4.35 & 15.41 & 48.9 & - & - & - & 40.32 & - & 85.9 & - & - & - \\
\hline & IP & - & 90 & 139 & - & & & 81 & - & 81 & - & - & - \\
\hline \multirow{2}{*}{$\begin{array}{l}\text { Sihen et al.., } \\
2012\end{array}$} & WS\% & - & - & - & - & 31.3 & 2.9 & 16.3 & - & 62.9 & - & - & - \\
\hline & IP & - & _- & & - & - & & 94.7 & _ & 99.3 & & & \\
\hline \multirow{2}{*}{$\begin{array}{l}\text { Demelash, } \\
2013\end{array}$} & WS\% & - & - & 15.1 & - & - & 43.5 & - & - & 87.3 & 97.2 & 0 & 67.2 \\
\hline & IP & & & 141.7 & & & 67.6 & _- & _- & 84 & 60.7 & + & 98 \\
\hline \multirow{2}{*}{$\begin{array}{l}\text { Demelash } \\
\text { and Kifle, } \\
2015\end{array}$} & WS\% & 0 & 9.33 & 15.1 & 50.8 & 61.7 & 43.3 & - & - & - & 97.2 & - & - \\
\hline & IP & + & 160 & 141.7 & 80.3 & 109.7 & 67.7 & - & - & - & 60.7 & - & - \\
\hline \multirow{4}{*}{$\begin{array}{l}\text { Kifle et al., } \\
2015 \\
\text { Admikew, } \\
2017\end{array}$} & $\mathrm{WS} \%$ & - & - & 0 & - & & 54.2 & 38.8 & - & - & 88.6 & - & \\
\hline & IP & 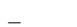 & 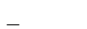 & + & 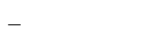 & 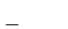 & 86 & 91 & 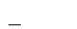 & & 91 & & _ \\
\hline & WS\% & 16.9 & 29.3 & 53.8 & 64.9 & 65.0 & 93.3 & 94.7 & 33.6 & 41.1 & 83.9 & 6.8 & _- \\
\hline & IP & 119.7 & 118.2 & 121.7 & 107.2 & 98.0 & 73.7 & 71.0 & 129.2 & 112.3 & 81.5 & 155 & \\
\hline \multirow{2}{*}{ Mean } & WS\% & 7.1 & 18.0 & 26.6 & 47.0 & 47.2 & 34.1 & 50.7 & 33.6 & 69.2 & 91.0 & 3.4 & 45.2 \\
\hline & IP & 119.7 & 122.7 & 136.0 & 112.5 & 107.9 & 88.2 & 95.7 & 129.2 & 95.8 & 78.3 & 155 & 125.3 \\
\hline
\end{tabular}

'+' = a genotypes not showed wilting symptoms in the tested period (6 months after inoculation), ' '= authors were not test that particular genotypes at that period, $W S \%=$ wilted seedling percentage and IP $=$ incubation period.

\section{Relationship of resistance at field and artificial inoculation test}

In Robusta coffee genotypes, there was an overall significant correlation $(P=0.002)$ between mortality in the field and mortality of cuttings in the screen house as shown in Table 2. This indicates that resistance detected in artificial inoculation is depicted in the field. Therefore, artificial inoculation is a good protocol for screening germplasm for resistance. Furthermore, correlations between mortality among open pollinated progenies in the screen house and their parents in the field and in artificial inoculation (rooted cuttings) were not significant; then, the response of open pollinated seedlings do not effectively represent CWD resistance of their parents for Robusta coffee (Musoli et al., 2009). In Tanzania, study also showed that clones of C. canephora consistently indicating resistance from the screen house to the field test (Kilambo et al., 2007).

Apparently, disease-free (tolerant) trees in the field can be selected and evaluated for true resistance through repeated seedling inoculation tests under controlled conditions in Arabica coffee at JARC, Ethiopia. Based on Artificial inoculation test, genotypes 1579 (12.7\%), 200/71 (15.2\%) and Merdacheriko (25.2\%) showed CWD resistant accompanied by long incubation periods; whereas Caturra and Geisha genotypes revealed highly susceptible as shown in Table 3 . There was also a positive correlation between seedling death rates in the greenhouse and wilt severity in the fields (Girma and Chala, 2008). Thus, those Arabica coffee genotypes demonstrating resistant reaction under both field and greenhouse conditions can be recommended for utilize in CWD-prone areas if they provided other desirable traits like resistance to CBD, high yielding and superior quality (Girma et al., 2009). 
Table 2: some Robusta and Arabica coffee genotypes (clones) reactions to CWD at field and artificial inoculation test.

\begin{tabular}{|c|c|c|c|c|c|c|c|c|}
\hline \multirow[b]{2}{*}{$\begin{array}{l}\text { Robusta } \\
\text { coffee } \\
\text { clones } \\
\end{array}$} & \multirow[b]{2}{*}{$\begin{array}{l}\text { Field } \\
\text { mortality }\end{array}$} & \multicolumn{2}{|c|}{ Screen house test } & \multirow[b]{2}{*}{$\begin{array}{l}\text { Arabica } \\
\text { coffee } \\
\text { genotypes }\end{array}$} & \multirow{2}{*}{$\begin{array}{l}\text { Mean } \\
\text { wilted } \\
\text { seedling } \\
(\%) \\
\end{array}$} & \multirow[b]{2}{*}{$\begin{array}{l}\text { Transformed } \\
\text { value(arcsine) }\end{array}$} & \multirow{2}{*}{$\begin{array}{l}\text { Incubation } \\
\text { period } \\
\text { (mean no. } \\
\text { days) }\end{array}$} & \multirow[b]{2}{*}{$\begin{array}{l}\text { Incidence } \\
\text { in the } \\
\text { field }^{\mathrm{a}}\end{array}$} \\
\hline & & $\begin{array}{l}\text { Rooted } \\
\text { cuttings }\end{array}$ & $\begin{array}{l}\text { Open } \\
\text { pollinated } \\
\text { progenies }\end{array}$ & & & & & \\
\hline $\mathrm{J} / 1 / 1$ & $0.0 \mathrm{a}$ & $15.0 \mathrm{~b}$ & - & 1185 & 86 & $75.1 \mathrm{ab}$ & 90.0 op & 75 \\
\hline $\mathrm{Q} / 3 / 4$ & $4.2 b$ & $20.0 \mathrm{~b}$ & _- & 1785 & 78.7 & $67.9 \mathrm{a}-\mathrm{h}$ & $80.0 \mathrm{p}$ & 75 \\
\hline $1 \mathrm{~S} / 3$ & $33.3 \mathrm{c}$ & - & 35.0abcd & 1579 & 12.7 & $16.9 \mathrm{~s}$ & $157.5 \mathrm{a}$ & 10.2 \\
\hline $\mathrm{R} / 1 / 4$ & $33.3 \mathrm{c}$ & $44.4 b c$ & 35.0abcd & 2179 & 63.3 & $53.4 \mathrm{i}-\mathrm{O}$ & $140.8 \mathrm{a}-\mathrm{d}$ & 20.5 \\
\hline $\mathrm{C} / 6 / 1$ & $50.0 \mathrm{~cd}$ & - & 65.0def & Apr-70 & 77.2 & $62.0 \mathrm{~b}-1$ & $117.5 \mathrm{~d}-\mathrm{m}$ & 56.2 \\
\hline $\mathrm{Q} / 6 / 1$ & $50.0 \mathrm{~cd}$ & _- & $80.0 \mathrm{fg}$ & $36 / 70$ & 60.9 & 56. $\mathrm{f}-\mathrm{n}$ & $92.5 \mathrm{n}-\mathrm{p}$ & 15.3 \\
\hline $\mathrm{B} / 2 / 1$ & $54.2 \mathrm{~cd}$ & $0.0 \mathrm{a}$ & $10.0 \mathrm{a}$ & $146 / 71$ & 34.6 & $35.1 \mathrm{qr}$ & $122.5 \mathrm{~d}-\mathrm{k}$ & 68.4 \\
\hline $223 / 32$ & $58.3 \mathrm{cde}$ & $90.0 \mathrm{~d}$ & $65.0 \mathrm{def}$ & $200 / 71$ & 15.2 & $20.3 \mathrm{~s}$ & $152.5 \mathrm{afb}$ & 28.2 \\
\hline $\mathrm{L} / 2 / 7$ & $62.5 \mathrm{def}$ & $50.0 \mathrm{bcd}$ & $25.0 \mathrm{abc}$ & $206 / 71$ & 52.8 & $46.1 \mathrm{~m}-\mathrm{q}$ & $125.0 \mathrm{~d}-\mathrm{j}$ & 48.9 \\
\hline $\mathrm{Q} / 1 / 1$ & $66.7 \mathrm{defg}$ & _ & $53.0 \mathrm{cde}$ & 8112 & 74.9 & $63.2 \mathrm{a}-\mathrm{k}$ & $112.5 \mathrm{f}-\mathrm{o}$ & 63.1 \\
\hline $\mathrm{B} / 1 / 1$ & 75.0defgh & _- & $85.0 \mathrm{fg}$ & 8133 & 64.2 & $54.1 \mathrm{~g}-\mathrm{n}$ & $122.5 \mathrm{~d}-\mathrm{k}$ & 19.2 \\
\hline $257 / 53$ & 83.3efgh & $25.0 \mathrm{~b}$ & $40.0 \mathrm{bcde}$ & Merdacheriko & 25.3 & $29.6 \mathrm{rs}$ & $150.0 \mathrm{a}-\mathrm{c}$ & 29.4 \\
\hline $\mathrm{G} / 3 / 7$ & $83.33 \mathrm{efgh}$ & $80.0 \mathrm{~cd}$ & $50.0 \mathrm{cde}$ & 8143 & 61.6 & $52.7 \mathrm{j}-\mathrm{p}$ & $125.0 \mathrm{~d}-\mathrm{j}$ & 42.4 \\
\hline $\mathrm{P} / 5 / 1$ & $87.5 \mathrm{fgh}$ & - & - & 8144 & 40.2 & $39.1 \mathrm{o}-\mathrm{r}$ & $137.5 \mathrm{a}-\mathrm{e}$ & 37 \\
\hline $\mathrm{E} / 3 / 2$ & $87.5 \mathrm{fgh}$ & _ & $25.0 \mathrm{abc}$ & $\mathrm{F}-27$ & 81 & $67.0 \mathrm{a}-\mathrm{j}$ & 90.0 op & 10.9 \\
\hline $1 \mathrm{~S} / 2$ & $87.5 \mathrm{fgh}$ & $100 \mathrm{e}$ & $20.0 \mathrm{ab}$ & F-35 & 85.7 & $70.9 \mathrm{a}-\mathrm{e}$ & $97.51-p$ & 26.2 \\
\hline $\mathrm{P} / 3 / 6$ & $91.7 \mathrm{gh}$ & - & 69.0efg & Caturra & 68.9 & $59.2 \mathrm{~d}-\mathrm{m}$ & $130.0 \mathrm{~b}-\mathrm{h}$ & 74.5 \\
\hline $\mathrm{B} / 6 / 2$ & $91.7 \mathrm{gh}$ & - & 68.0efg & Geisha & 88.1 & $73.9 \mathrm{a}-\mathrm{c}$ & $97.51-\mathrm{p}$ & 29.1 \\
\hline $\mathrm{H} / 4 / 1$ & $94.4 \mathrm{gh}$ & $70.0 \mathrm{~cd}$ & $60.0 \mathrm{def}$ & $7440^{\mathrm{b}}$ & 40.4 & $38.7 \mathrm{p}-\mathrm{r}$ & $135.0 \mathrm{a}-\mathrm{f}$ & 20.3 \\
\hline \multirow[t]{4}{*}{$\mathrm{C} / 1 / 7$} & $95.8 \mathrm{~h}$ & $63.6 \mathrm{~cd}$ & $95.0 \mathrm{~g}$ & $\mathrm{SN}-5^{\mathrm{c}}$ & 69.7 & $56.7 \mathrm{e}-\mathrm{n}$ & $119.2 \mathrm{~d}-1$ & 99.9 \\
\hline & & & & $\begin{array}{l}\text { Mean } \\
\operatorname{LSD}(P<\end{array}$ & 68.8 & 58.3 & 115.5 & - \\
\hline & & & & $0.05)$ & - & 14.4 & 23.5 & - \\
\hline & & & & CV $(\%)$ & - & 21.8 & 17.9 & \\
\hline
\end{tabular}

'_' means data are not available; Means with the same letters are not statistically significant different; Arabica genotypes mean wilted seedling percentage were average of two years data and transformed to arcsine square root values before analysis.

a CWD incidences (mean \%) summarized from various fields and localities (Girma, 1997; Girma et al., 2001; Girma, 2004).

b Resistant (tolerant) cultivar; c Susceptible checks; LSD = least significant difference.

\section{Genetics of resistance}

Inheritance is the transmission of genetic information from parents to progeny. This transmission mechanism of genetic information is paramount and important to design effective breeding methods to any crops. The most important considerations to know about traits inheritance are whether dominant or recessive gene controlled resistance; or it controlled by monogenic, oligo-genic or polygenic; and whether or not cyto-plasmic inheritance is involved. Furthermore, the relative importances of additive and non-additive gene actions (dominance and epistasis) are also useful in controlling traits and to decide appropriate breeding method (Schlegel, 2003). Therefore, understanding the inheritance of resistance mechanism and the type of resistance are necessary to determine appropriate breeding program to develop CWD resistant varieties (Musoli et al., 2009).

According to Musoli et al. (2013), the inheritance of resistance to F. xylarioides in crosses of $C$. canephora using partial diallel progeny (a half-sib progeny) test suggesting polygenic control of resistance. In addition, broad sense heritability and narrow sense heritability was moderate $(0.33)$ and low $(0.11)$, respectively. This showed that only about $33 \%$ CWD resistance is heritable from parents to progenies and genetic gains of choosing a progeny of resistant parents as source of planting materials for production are low. Therefore, resistant Robusta coffee varieties should be propagated vegetatively to retain the resistance. In Arabica coffee seedling and conidium germination test on six host genotypes with four $G$. xylarioides isolates conclude that the resistance is a horizontal nature (Pieters and Van der Graaff, 1980). There were also highly significant differences among genotypes, isolates and cultivar-isolate interactions in seedling test; suggesting the presence of certain qualitative (vertical) with quantitative (horizontal) resistance reaction (Girma et al., 2009). Moreover, 
The study on eight Arabica coffee parents and 28 crosses with susceptible check result showed that lacking of better parent heterosis $(\mathrm{BPH})$ and low mid parent heterosis $(\mathrm{MPH})$ for CWD resistance, predominance of additive over non additive gene actions and estimated high broad sense heritability coupled with high GAM for resistance and incubation period; indicates selection and hybridization are important to improve population and to obtain segregating generation, respectively. Moreover, CWD resistant genotypes were significantly associated with extended incubation period, leaf area, stem diameter and minimum number of defoliated leaves than the susceptible genotypes (Admikew, 2017).

However, the inheritance mechanisms of Fusarium wilt in other crops are different. In Pima cotton Fusarium wilt race 4 resistance differences detected between F1 hybrids and the mean of the parents in foliar symptoms and vascular discoloration; the bimodal distribution observed on the recombinant inbred line (RIL) population provide strong evidence for a dominant gene effects (Ulloa et al., 2006). According to Changaya et al. (2012), one to two genes governing Fusarium wilt resistance in pigeon pea. The inheritance of resistance to Verticillium wilt (caused by both the defoliating (D) and non-defoliating (ND) pathotypes of Verticillium dahlia) in cotton also confirmed that a single dominant gene controlled the defoliating pathotype; while the nondefoliating pathotype is governed by dominant alleles at two loci (Mert et al., 2005).

\section{Hybridization for resistance}

Hybridization is a method of breeding; new cultivar that utilizes crossing to obtain genetic recombination or it is the crossing of individuals of unlike genetic constitution. Selfing and crossing are essential procedures in the hybridization program. The exact employed procedures depend upon the crop species, the structure of the floral organs, and the type of pollination; i.e., cross pollination or self-pollination (Poehlman and Sleper, 1995).

Hybrids have been generated through artificial pollination to combine CWD resistant clones or genotypes and the complementary traits found in the commercial clones or varieties. The hybrid progenies generated in such crosses are evaluated as individual trees for resistant and agronomic traits starting at the screen house through field testing at Uganda. Then, best performing individuals (genotypes) selected, cloned and planted in multi-location trials for adaptation and adoption tests and released to farmers (Musoli et al., 2009). It is expected that progenies involving parents from different population and distant geographical locations intend to benefit from hybrid vigor; derived from double heterozygosity of the parents. However, the derived hybrid progenies were not significantly resistant than the parental lines. Due to the specificity of the pathogen populations affecting the different commercial coffee species, resistant varieties can be also derived through inter-specific hybridizations; even though it is complicated and difficult to derive a variety of desired quality (Phiri and Baker, 2009). In Arabica coffee, there was no overall genetic improvement in the favorable direction through crossing; even though some individual crosses showed lower wilted seedling percentage than the corresponding parents. Generally, neither parents nor crosses showed exempt to the disease (Admikew, 2017).

\section{Grafting}

The resistance mechanism of coffee against wilt pathogen is not well known. If CWD resistant rootstock can prevent the pathogen from reaching the scion (varieties with good agronomic characteristics but CWD susceptible), grafting on to a resistant rootstock could be a good and probably quicker means of deriving appropriate coffee planting materials. In Uganda, grafting of current commercial clones on to resistant clones are being evaluated for compatibility and the ability of rootstock to prevent the disease from getting through the vascular system of the rootstock to the scion (Phiri and Baker, 2009). Successful inter specific grafting involving C. canephora and Coffee liberica species has been reported (Couturon, 1993). However, according to Bertrand et al. (2001), there is depressing effects of rootstock ( $C$. liberica species) on yield and quality of Arabica coffee scion varieties. Therefore, other agronomic properties of the grafted varieties such as yield and quality should be studied and well understood before recommending for planting to farmers (Musoli et al., 2009).

\section{CWD resistant varieties development}

Breeding for a new coffee variety normally takes about 20 years to complete enough crosses and backcrosses with existing genotypes that provide the other required qualities (yield, cup quality, resistance to other diseases) to produce a final product that has all the characteristics (Phiri and Baker, 2009). The possible breeding perspectives for Robusta and Arabica CWD resistant variety development is shown in Figure 7 and 8 , respectively.

A breeding program in Uganda has screened 1519 Robusta genotypes for CWD resistance through mass screening of coffee seedling and cuttings (Musoli et al., 2009). Further screening and evaluation of other important traits have reduced to seven final candidates for released. In Tanzania, out of 875 Robusta coffee lines, 201 resistant genotypes have been identified through mass screening of germplasm and six resistance lines were selected and under evaluation. The resistant genotypes have been planted in mother gardens for vegetative multiplication. Screening study in DRC reported also that 35 coffee lines were already collected and established 
in two CWD infected areas (Phiri and Baker, 2009).

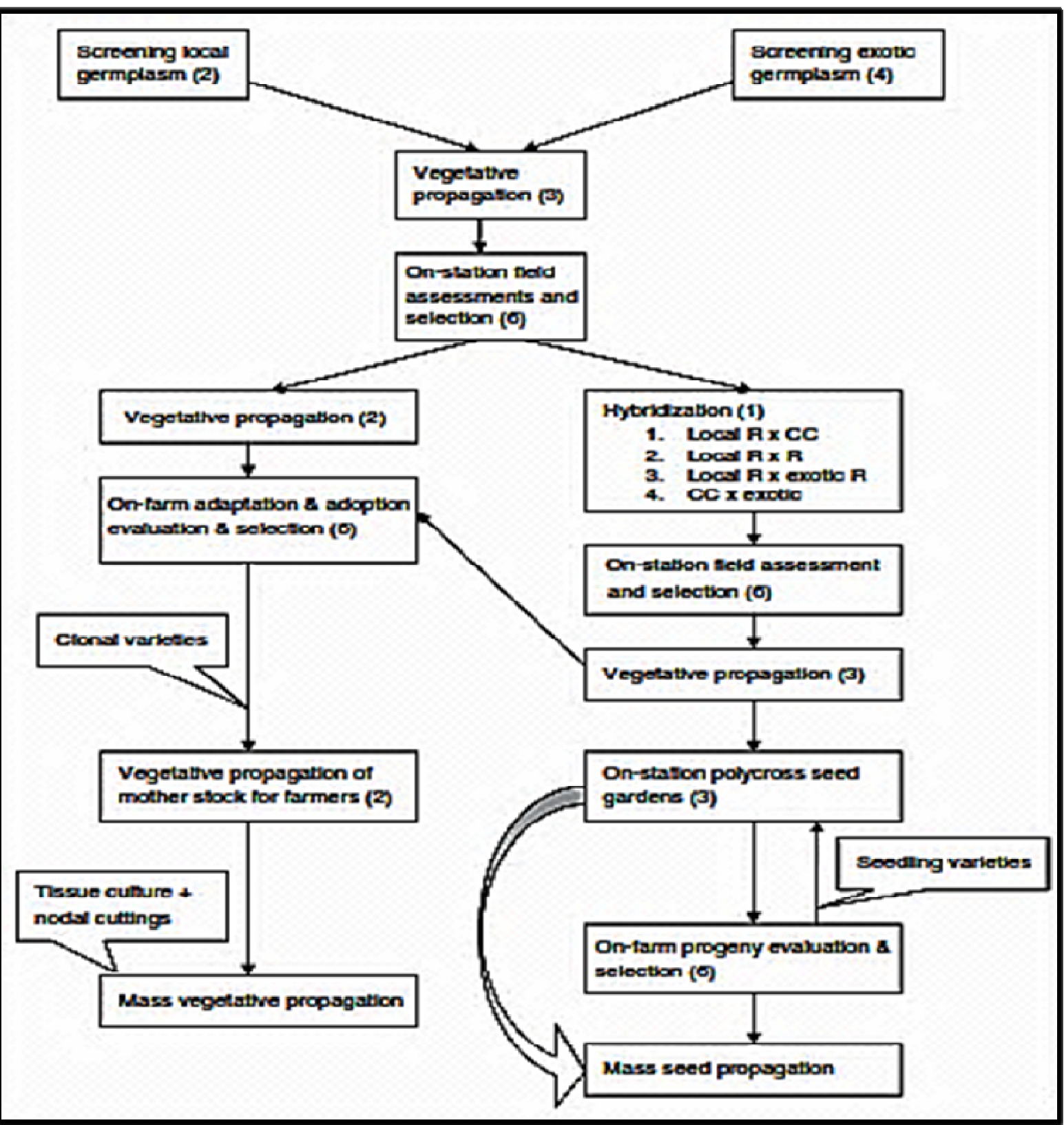

Figure 7: Proposed scheme for developing CWD resistant Coffea canephora varieties (Musoli et al., 2009); $R=$ resistant and $C C=$ current commercial varieties.

In Ethiopia, most of the released Arabica coffee cultivars are susceptible to CWD (Demelash and Kifle, 2015). Nevertheless, Sidama or Yirgachefe varieties; Fayate and Odicha show high to moderate resistant among the released varieties (Chala et al., 2012). According to Demelash (2013) coffee genotypes 370 and 279/71 indicated resistances as compared to resistant check (catimor-19). Furthermore, cultivar Merdacheriko is considered as moderately resistant in greenhouse test (Girma, 2004).

Generally, CWD resistant genotypes at green house test must be undergoing preliminary field evaluation for important traits, such as yield, resistance to other diseases and qualities. Using this approach, report showed that seven resistant Robusta clones were identified and released in Uganda (Musoli et al., 2013). In Ethiopia, further evaluation of promising resistant genotypes at sick plot and field evaluation for major diseases, yield and quality is under progress (Kifle et al., 2015). 


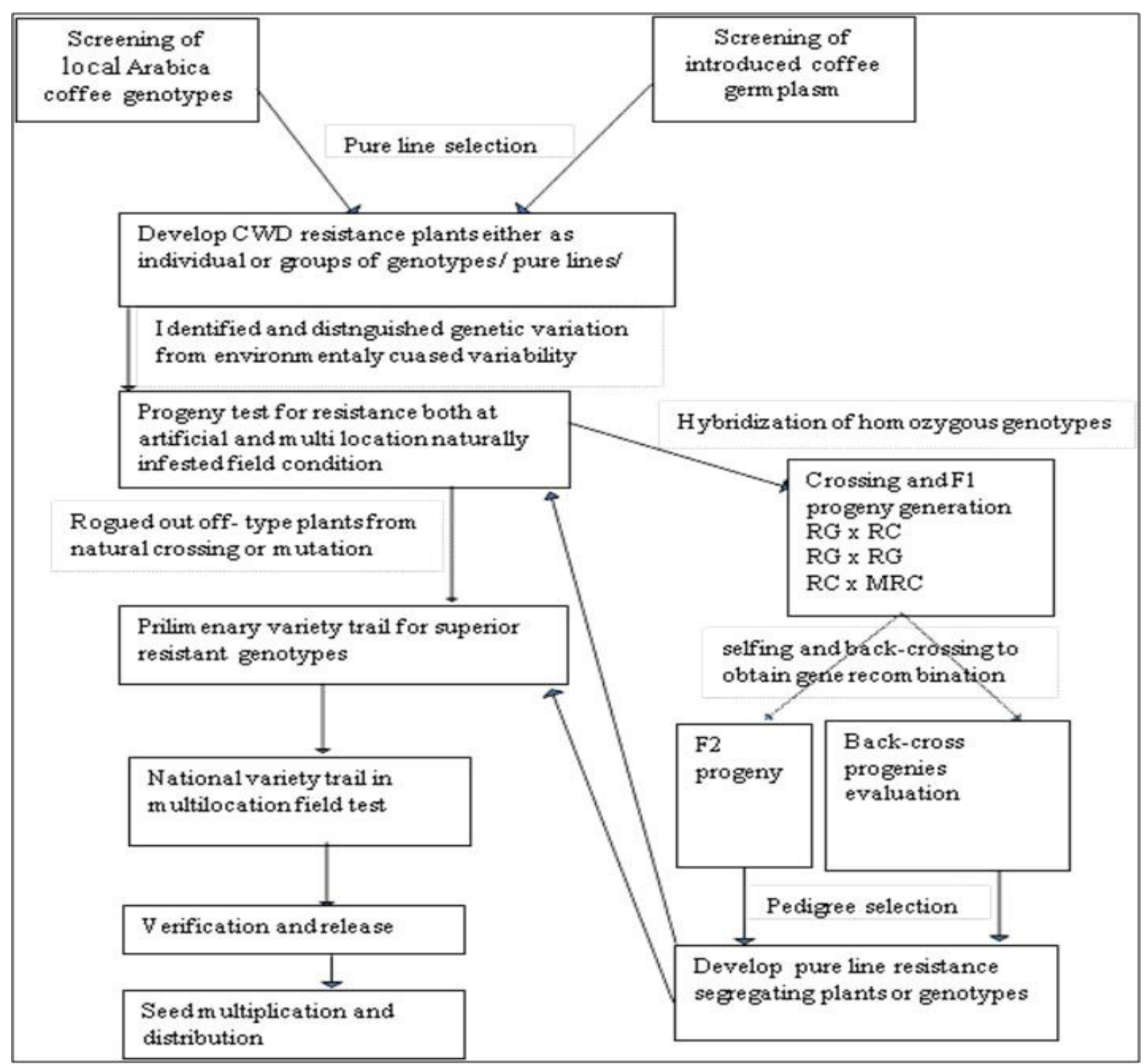

Figure 8: Future scheme for developing CWD resistant Coffea arabica varieties; $R G=$ resistant genotype, $R C=$ Resistant cultivar and MRC = moderately resistant cultivar.

\section{Conclusion}

Coffee wilt disease (tracheomycosis) is a fungal vascular disease caused by Fusarium xylarioides (sexual form, G. xylarioides). Currently, it affects coffee production and productivity severely. Various methods were evaluated to establish a simple, reliable and cost-effective way of evaluating coffee genotypes to resistance; root dipping and stem nicking are the two preferred methods. Furthermore, the study of host-pathogen associations involves a three-dimensional interaction between host (coffee genotypes), wilt pathogen strains and environmental variables. Intra- and inter specific differences among and between coffee species respectively provide potential genetic variability; which is exploited for resistance. Understanding the inheritance of resistance is necessary for resistant varieties development. CWD resistance in coffee canephora is quantitative and low to moderate heritability. Therefore, there is low genetic gain of choosing a progeny of resistant parents as source of planting materials and resistant Robusta varieties should be propagated as vegetative. However, in Arabica coffee high heritability and both additive and non additive genetic effects were observed even though further genetic study should be made.

There are two pathogenic forms within CWD populations and suggested that the information enables to design effective management strategies, develop resistant cultivars (clones) and formulate further breeding programs towards each population group. In Uganda, seven CWD resistant Robusta clones were identified and released. There is marked differences in resistance levels in Arabica coffee populations under field conditions. There were also highly significant differences among cultivars, the isolates and cultivar-isolate interactions in seedling test; suggesting presence of certain qualitative (vertical) reaction with quantitative (horizontal) resistance. In Ethiopia, among the released cultivars, Fayate and Odicha showed high to moderate resistance. 


\section{Recommendation}

From the review, general recommendations are as follow;

There should be CWD resistant genotypes evaluation at multi-site, multi-year on wilt devastated areas both on-station and on-farm using well designed experiment in order to develop wilt resistant varieties especially in Arabica coffee. The resistant genotypes should be also evaluated for major diseases, yield and other important traits.

Further study on parents, $F_{1}, F_{2}$, back cross $(B C)$ generations should be indispensable in order to obtain resistant segregate generation after hybridization, to determine the number of genes controlling resistance and the exact breeding method both at artificial inoculation and multi-location (naturally infested field condition) test.

Screening of resistant genotypes through artificial inoculation method is rather time and space consuming to screen out resistant genotypes. Hence, efficient and reliable disease screening methods, such as in vitro screening protocol should be used to select CWD resistant genotypes which will be advantageous for future screening program; it takes short time and small space. It may not also needs to take fruits and sowing seed; because sample should be taken from any plant parts at any time to grow callus or suspension culture cells in the presence of a fungal culture filtrate containing toxic metabolites produced by the pathogen.

So far, in Ethiopia, grafting of resistant rootstock on to susceptible scion is not implemented due to absence of resistant rootstocks. Additionally, some investigators suggest their view that grafting may not be effective to control the disease due to that the transmission is not only from roots but also from any plant parts contact. So, grafting is important to examine whether prevent the disease or not under experimentation.

QTL mapping study is needed for marker assisted selection.

The mechanism of pathogen attack and the host (coffee) resistance mechanism need a detail study in the future; which is a basic gap in order to develop CWD resistant cultivars.

Conflict of Interest: The author has not declared any conflict of interest.

\section{Acknowledgments}

Firstly, my deep and heart full gratefulness is for the supreme power, God. Next, I wish to thank Jimma University, Collage of Agricultural and Veterinary Medicine, Horticulture and Plant Science Department. My special thanks extend to all the authors to access their works as a reference.

\section{REFERENCES}

Admikew, G., (2017). Mode of inheritance of resistance to coffee wilt disease (G. xylarioides Heim and Saccas) in Arabica coffee (Coffea arabica L.) genotypes. M. Sc thesis, Jimma University, Ethiopia.

Agrios, N., (2005). Plant pathology. Elsevier Academic Press, USA. p922.

Alemu, T., (2012). A review of coffee wilts disease, G. xylarioides (Fusarium xylarioides) in Africa with special reference to Ethiopia. Ethiop. J. Biol. Sci., 11(1): 65-103.

Arega, Z., (2006). Diversity of Arabica coffee population in afro-mountain rainforests of Ethiopia in relation to Colletotrichum kahawae and Gibberella xylarioids. M. Sc thesis, Addis Ababa University, Ethiopia.

Beckman, H., (1987). The nature of wilt diseases of plants. APS Press, St. Paul, MN, USA.

Bertrand, B., Etienne, H., and Eskes, A., (2001). Growth, production and bean quality of Coffea arabica as affected by inter-specific grafting: consequences for rootstock breeding. In: Proceedings of American Society for Horticulture Annual conference No. 96. Minneapolis, Minnesota.

Bieysse, D., (2005). Development of a long-term strategy based on genetic resistance and agro-ecological approaches against coffee wilt disease in Africa: Fourth Annual Report. INCO-DEV Contract ICA4-CT2001-10006. CIRAD-AMIS, Montpellier, France.

CABI., (2003). Surveys to assess the extent of coffee wilt disease in East and Central Africa. Final technical report. CABI Regional Center, Nairobi, Kenya.

Chala, J., Girma, A., Demelash, T., Arega, Z., Shine, B., and, Adem, A., (2012). Development and release of coffee berry disease resistant varieties to specialty coffee producing regions in Ethiopia. Jimma Agricultural Research Centre, Ethiopia.

Changaya, AG., Melis, R., Derera, J., Laing, M., and Saka, V W., (2012). Inheritance of resistance to fusarium wilt and yield traits in pigeon pea. Euphytica, 186: 883-896.

Couturon, E., (1993). Demonstration of different levels of afferent specific grafts in coffee trees. In: $15^{\text {th }}$ symposium of the International scientific Coffee Association, Montpellier, France.

Demelash, T., (2013). Evaluation of Arabica coffee (coffea Arabica L.) germplasm for major coffee disease with special emphasis to coffee wilt disease (Gibberella xylarioides) at Jimma, Ethiopia. M. Sc thesis, Jimma University, Ethiopia.

Demelash, T., and Kifle, B., (2015). Evaluation of released Arabica coffee varieties (Coffea aabica L.) for major coffee diseases with special emphasis to coffee wilt disease (G. xylarioides) at Jimma, Ethiopia. Journal of Biology, Agriculture and Healthcare, 5(15). 
Geiser, DM., Ivey, MLL., Hakiza, G., Juba, JH., and Miller, SA., (2005). Gibberella xylarioides (anamorphous: Fusarium xylarioides), a causative agent of coffee wilt disease in Africa: A previously unrecognized member of the G. fujikuroi species complex. Mycologia, 97: 191-201.

Girma, A., and Mengistu, H., (2000). Cultural characteristics and pathogenicity of Gibberella xylarioides isolates on coffee. Pest management Journal of Ethiopia, 4:11-18.

Girma, A., (1997). Characterization of Gibberella xylarioides Heim and Saccas (Fusarium wilt) of coffee (Coffea arabica L.). M. Sc thesis, Alemaya University, Ethiopia. p100.

Girma, A., Mengistu, H., and Hindorf, H., (2001). Incidence of tracheomycosis, Gibberella xyilarioides (Fusarium xylarioides) on Arabica coffee in Ethiopia. J. Plant Dis. and Pro., 108 (2):136-142.

Girma, A., (2004). Diversity in pathogencity and genetics of Gibberella xyilarioides (Fusarium xylarioides) population and resistance of coffee spp. in Ethiopia. Doctoral dissertation, University of Bonn, Germany.

Girma, A., Biyesse, D., and Musoli, P., (2009). Host pathogen interaction in Coffea Gibberella xylariodes pathogen System. In: Flood, J. (eds.) Coffee Wilt Disease, CAB international, UK. pp.120-136.

Girma, A., Hindorf, H., Steiner, U., Nirenberg, HI., Dehne, H W., and Schellander, K., (2005). Genetic diversity in the coffee wilt pathogen (Gibberella xyilarioides) populations: differentiation by host specialization and RAPD analysis. J. Plant Dis. and Pro., 112 (2): 134-145.

Girma, A. and Chala, J., (2008). Resistance levels of Arabica coffee cultivars to coffee berry disease, coffee wilt and leaf rust diseases in Ethiopia. In: Proceedings of the $7^{\text {th }}$ Crop Science Society of Ethiopia (CSSE), 22-24 May 2006, Addis Ababa, Ethiopia.

Heim, R., and Saccas, A., (1950). Tracheomycosis of Coffea excelsa and robusta in the plantations of OubanguiChari. CompteRendu de l'Academie des Science, 231(11):536-538.

Kalonji-Mbuyi, A., Tshilenge Djim P., and Saiba NT., (2009). Coffee Wilt Disease in Democratic Republic of Congo. In: Flood, J. (eds.) Coffee Wilt Disease, CAB international, UK. pp.7-27.

Kifle, B., Demelash, T., and Gabisa, G., (2015). Screening of some coffee Arabica genotypes against coffee wilt diseases (G. xylarioides, Heim and Saccus). International Journal of Sustainable Agricultural Research, 2(3): 66-76.

Kilambo, DL., Ng'homa, NM., Mtenga, DJ., Teri, JM., and Phiri, N., (2012). Progress in breeding for resistance to coffee wilt disease (tracheomycosis) in Tanzania. World research journal of agricultural and biosystems engineering, 1 (1):12-16.

Kilambo, DL., Ng'homa, NM., Mtenga, DJ., Teri, JM., Nzallawahe, T., Mike, R., and Masumbuko1, L., (2007). Progress towards searching for durable resistance to Fusarium wilt (Fusarium xylarioides) in Coffea canephora germplasm in Tanzania. In: Proceedings of the $20^{\text {th }}$ International Scientific Conference on Coffee Science(ASIC), Bangalore, India. pp.1386-1389.

Kranz, J., and Mogk, M., (1973). G. xylarioides Heim and Saccas on Arabica coffee in Ethiopia. Phytopath. Z., 78: $365-366$

Leakey, CLA., (1970). The improvement of Robusta coffee in East Africa. In: Leakey, C.L.A. (eds.) Crop Improvement in East Africa, CAB International, Wallingford, UK. pp.250-277.

Merdassa, E., (1986). A review of coffee diseases and their control in Ethiopia. In: Tsedeke, A. (eds.) Proceedings of the First Ethiopian Crop Protection Symposium, 4-7 February 1986. IAR, Addis Ababa, Ethiopia. pp.187-195.

Mert, M., Kurt, S., Gencer, O., Akiscan, Y., Boyaci, K., and Tok, FM., (2005). Inheritance of resistance to Verticillium wilt (Verticillium dahliae) in cotton (Gossypium hirsutum L.). Plant Breeding, 124:102-104.

Musoli, PC., Cilas, C., Pot, D., Nabaggala, A., Nakendo, S., Pande, J., Charrier, A., Thierry, L., and Bieysse, D., (2013). Inheritance of resistance to coffee wilt disease (Fusarium xylarioides Steyaert) in Robusta coffee (Coffea canephora Pierre) and breeding perspectives. Tree Genetics \& Genomes 9:351-360.

Musoli, PC., Girma, A., Hakiza, GJ., Kangire, A., Pinard, F., Agwanda, C., and Bieysse, D., (2009). Breeding for Resistance against Coffee Wilt Disease. In: Flood, J. (eds.) Coffee Wilt Disease, CAB international, UK. pp.180-197.

Musoli, PC., Pinard, F., Charrier, A., Kangire, A., ten Hoopen, GM., Kabole, C., Ogwang, J., Bieysse, D., and Cilas, C., (2008). Spatial and temporal analyses of coffee wilt disease caused by Fusarium xylarioides in Coffea canephora. Eur. J Plant Pathol., 122:451-460.

Musoli, PC., (2007). Sources of resistance against coffee wilt disease caused by Fusarium xylarioides in Uganda. Doctoral dissertation, Montpellier II University, France.

Nelson, PE., (1981). Life cycle and epidemiology of Fusarium oxysporium. In: M. E. Mace, A. A. Bell and C. H. Beckman (eds.), Academic Press, London. pp.51-80.

Phiri, N., and Baker, P., (2009). Coffee Wilt disease in Africa. Final Technical Report of the Regional Coffee Wilt Programme, CAB international.

Poehlman, JM., and Sleper, DA., (1995). Breeding Field Crops. Iowa state university press, Ames, Iowa, 50014, India. 
Rutherford, MA., Bieysse, D., Lepoint, P., and Maraite, HMM., (2009). Biology, Taxonomy and Epidemiology of the Coffee Wilt Pathogen G. xylarioides sensual to Coffee Wilt Disease. CAB international. pp.124-139.

Schlegel, RHJ., (2003). Encyclopedic dictionary of plant breeding and related subjects. Haworth Press, Inc. Alice Street, Binghamton.

Serani, S., Taligoola, HK., and Hakiza, GJ., (2007). An investigation into Fusarium spp. associated with coffee and banana plants as potential pathogens of Robusta coffee. Afric. J. Ecol., 45: 91-95.

Sihen, G., Girma, A., Fikre, L., and Hindorf, H., (2012). Coffee wilt disease (G. xylarioides Heim and Saccas) in forest coffee systems of Southwest and Southeast Ethiopia. Plant Pathol. J., 11(1): 10-17.

Silva, MC., Várzea, V., Guerra-Guimarães, L., Azinheira, HG., Fernandez, D., Petitot, AS, Bertrand, B., Lashermes, P., and Nicole, M., (2006). Coffee resistance to the main diseases: Leaf rust and Coffee Berry Disease. Braz. J. Plant Physiol., 18(1): 119-147.

Steyaert, RL., (1948). Contribution to the study of plant parasites of the Belgian Congo. Bulletin of the Royal Botanical Society of Belgium, 80:11-58.

Strange, RN., (1993). Plant Disease Control: Towards environmentally acceptable methods. Chapman and Hall, New York.

Toole, ER., (1941). Fusarium wilt of mimosa tree (Albizia julibrisin). Phyopath., 31: 599-616.

Ulloa, M., Hutmacher, RB., Davis, RM., Wright, SD., Percy, R., and Marsh, B., (2006). Breeding for Fusarium wilt race 4 resistance in cotton under field and greenhouse conditions. J. Cotton Sci., 10(11):114-127.

Van der Graaff, NA., and Pieters, R., (1978). Resistance levels in Coffea arabica to G. xylarioides and distribution pattern of the disease. Neth. J.Pl. Pathol., 84: 117-120.

Van der Graaff, NA., and Pieters, R., (1980). Gebberrella xyilarioides on Arabica coffee: Evaluation of testing methods and evidence for the horizontal nature of Resistance. Neth. J. Pl. Path., 86:37-43. 